\title{
The Chinese and the chief's tree: framing narratives of socionature and development in Kibwezi, Kenya
}

\author{
Mark Lawrence \\ Department of Geography, Center for Sustainability Studies, Bemidji State University, \\ Bemidji, Minnesota 56601, USA \\ Correspondence: Mark Lawrence (mark.lawrence@ bemidjistate.edu)
}

Received: 13 May 2020 - Revised: 24 March 2021 - Accepted: 6 April 2021 - Published: 12 May 2021

\begin{abstract}
China's Belt and Road Initiative (BRI) exploits increased permeability of all kinds of boundaries even as old rhetorics of sovereign space are reanimated. This paper examines a very local example of impacts in Kibwezi, Kenya. Regarding more than a century of local land disputes, BRI's "dreamscape" (Jasanoff and Kim, 2015) can be repurposed especially given persistence of sacred geographies of wood and water access. These mathembo landscapes are less refuges for emasculated traditional customs and institutions than resources that are as much affective as they are material in their revitalization to meet the contexts of changed times. Such "socionatures" (Swyngedouw, 1996) energize multiple answers to questions of who gets to imagine the future and how much latitude others have to participate in particular designed futures as they see fit. As it turns out, dreamscapes may be opposed not only by equally grandiose alternative narratives but also by more localized imaginaries, and while dreamscapes are future-oriented, alternatives referencing the past can compete well.
\end{abstract}

\section{Introduction}

By 2018, countries and organizations in Asia, Europe, and Africa representing $40 \%$ of global GDP had signed trade and infrastructure deals with China as part of its Belt and Road Initiative (BRI). BRI's flagship project in East Africa is the Standard Gauge Railway (SGR) effort to replace colonialera infrastructure with several new transportation corridors extending across Kenya to Uganda, South Sudan, the Democratic Republic of Congo, Rwanda, Burundi, and Ethiopia. Implementation of this enormous undertaking relies on discourse meant to unite many different sociocultural, political, economic, and environmental contexts (Flyvbjerg, 2005). But how successful are such "dreamscapes" (Jasanoff and Kim, 2015)? Likewise, must they be opposed only by equally grandiose alternative narratives, or do more localized imaginaries have a chance? While such discourses project visions of future developments are alternatives referencing the past comparatively inadequate? Answering these questions in the context of more than a century of local land disputes in Kibwezi, Kenya, reimagined pasts can be shown to animate cultural resistance to dreamscapes, megaproject narratives repurposed by those whom nominally they target.
Investigating the consequences of imposing dreamscapes on particular African contexts joins wider discussions advancing affective, nonrepresentational theory (Thrift, 2007; Pile, 2009) in geographic analysis. Before and beyond the situating of a locality within a discursive context, there are sentimental, nonrepresentational interactions of "taking-place" (Anderson and Harrison, 2010). The grand abstractions of BRI's dreamscape presume the ontological independence of something assigned a distinction we are all supposed to accept, while the nonrepresentational amounts simultaneously to what its originator intends and also to what others encountering it interpret it as. This deliberately unstable sense of a place as being in an endless process of becoming brings us into the orbit of affective theory since nonrepresentational approaches to the enactment of place "valorise those processes that operate before... conscious, reflective thought" (McCormack, 2005:122).

Focus on the affective challenges dreamscapes as significantly technological exercises in future-making. Enthusiasm for state-of-the-art technologies such as SGR's high-speed trains is persistently confronted by the "shock of the old" (Edgerton, 2006), prompting attention to which specific tech- 
nologies societies actually use as opposed to only those promoted. Moreover, what "technology" is understood to encompass when speaking about "sociotechnical imaginaries" (Jasanoff and Kim, 2015) needs to be critiqued. While those in Kibwezi discontented with SGR's arrival utilize such ubiquitous 21 st-century technologies as digital television, cellphones, mobile banking, and (ironically) even Chinese motorcycles, many of their reactions are couched in terms of "indigenous knowledge". While for a long time such ways of negotiating the world were characterized as parochial, science and technology studies (STS) and the study of indigenous knowledge more recently have experienced a convergence of assumptions, recognizing all knowledges as specific to particular cultural contexts. Even the claim to a universal scientific perspective is itself value-laden; only seemingly value-free, Western knowledge is no more rational than non-Western alternatives (Watson-Verran and Turnbull, 1995; Turnbull, 2000). As adjuncts to promotion of dreamscapes, science and technology are forms of social action, as are indigenous knowledges being deployed in Kibwezi.

But dreamscapes are not simply about technological innovation; effort is also needed to challenge them as "fabrications of power" (Jasanoff and Kim, 2015) from particular geopolitical centers. So, who gets to imagine the future, and how much latitude do others have to participate in particular designed futures as they see fit? Jasanoff and Kim (2009:123) associate sociotechnical imaginaries in the USA and South Korea "with active exercises of state power, such as the selection of development priorities, the allocation of funds, the investment in material infrastructures, and the acceptance or suppression of political dissent." Schiølin (2010) goes further, emphasizing that globalist sociotechnical imaginaries in Denmark promote a "future essentialism" to depoliticize dreamscapes by foreclosing democratic debate about their appropriateness. Smallman (2019) finds the instrumentality of government in the UK fortifying policymaking that implements dreamscapes against public opinion as characterized by having "Nothing to do with the science". But crucially for consideration of local responses to SGR's dreamscape, sociotechnical imaginaries have no necessary connection to state actors only. For instance, remote sensing technologies deployed by anti-war NGOs and other non-state analysts promoted a powerful imaginary in the early 2000s that Iran's Natanz nuclear facility was being constructed as part of a clandestine weapons program (Lawrence, 2020).

Heeding Bhabha's call for an "ex-centric" approach (Bhabha, 1994:6) means not only questioning China's optimism for its BRI projects in Africa but also avoiding assumptions there is anything like an equally generic "African" alternative to future-making. A world system conditioned by "global coloniality" (Ndlovu-Gatsheni, 2014) may limit such efforts to being defined in terms of Eurocentric versions of what development means. But examples from Kibwezi demonstrate a "local" sense of place often borrowing elements originating elsewhere to reframe the terms under which ideas and physical conditions of spatial reordering are debated. In Kibwezi, much of this involves particular trees and springs in the Ki-Kamba language called mathembo (singular, ithembo) as important sites for breaking down subjectobject distinctions which too often "homogenize the category 'nature' ... when it should be regarded as intensely internally variegated" (Harvey, 1996:183; see also Jones and Cloke, 2008). The view of such "socionature" (Swyngedouw, 1996) adopted here borrows from actor-network theory emphasizing the multiplicity of relations between human and nonhuman actants hybridizing agency in specific places (Whatmore, 2002). One example of that hybridization involves contemporary re-inscription of the identity as a "chief" more than a century ago of a historically important figure associated with mathembo landscapes named Kilundo Meli, whose actual presence was neither as authoritative nor as unproblematic as his promoters today would have it seem.

Answering the three questions posed at the outset requires (1) laying out SGR's prehistory in Kibwezi and then (2) describing how the dreamscape represents itself materially. Since SGR is just one example of a "travelling model" of development promoted as transposable to any number of other geographical scenarios (Behrends et al., 2014), it is also necessary (3) to situate the project within Kibwezi's particular physical circumstances before finally (4) confronting it with the affective, hybrid geographies calling into question its "fictional expectations" (Beckert, 2016). An important caveat is to make clear the observations presented here are not based on research directly targeting investigation of the impacts of BRI's dreamscape on Kibwezi. Instead, they arise from 2 decades of ethnographic research about changing patterns of human interaction with the physical environment, especially mapping mathembo landscapes with reference to convoluted histories of repeated population displacement and resettlement only most recently intersected by SGR's arrival. It should also be noted that a Vision 2030 campaign aimed at Kenya becoming a newly industrializing, middle-income country provides a partly competing, partly complementary "homegrown" dreamscape. But given this paper's more local focus, the Kenyan authorities' view of China's goals and how the government has reacted to local resistance to SGR throughout the whole of the country are not addressed here.

\section{Prehistory - from Mackinnon Road and the Lunatic Line to SGR}

Construction to replace the defunct railway line between Mombasa and Nairobi began in 2016 after China's staterun Exim Bank loaned Kenya $90 \%$ of the USD 3.6 billion cost. Although Kenyan taxpayers took on the debt, a Chinese company was awarded SGR's construction contract. African labor was included, but China sent thousands of workers and has kept a firm grip on both construction and operation of the new railway. Although unfinished, SGR nonethe- 
less officially opened in 2017 when the first Belt and Road Forum was held in Beijing to celebrate BRI achievements worldwide. In 2019, a second forum recalibrated expectations about delayed projects, with Kenya failing to obtain fresh loans to extend SGR all the way to the Ugandan border.

SGR first closely follows Mackinnon-Sclater Road, an early colonial effort to modernize older caravan routes, stretching $300 \mathrm{~km}$ from Mombasa to Kibwezi. Most of this initial interior region of Kenya is today referred to as Ukambani, designated homeland of the Akamba people. In the 1890s, imported South Asian labor built the meter-gauge Uganda Railway along roughly the same track, dubbed the "Lunatic Line" given exorbitant costs in personnel losses to disease, hostile indigenous populations, and predatory wildlife. Already woefully antiquated by Kenya's independence in 1963, when the railway was shut down officially in 2017 the $488 \mathrm{~km}$ journey between Mombasa and Nairobi could easily last $24 \mathrm{~h}$. Today, SGR's trains make the trip in just $5 \mathrm{~h}$.

Despite proximity to the railway, the highway that replaced Mackinnon Road, and the Kenya Pipeline Company oil distribution artery, Kibwezi Division for many decades remained a backwater. In 1999 running water and electricity existed only in a handful of government facilities, the sole bank informally renting public use of its one landline telephone (personal observation). With about 3000 people in Kibwezi town and nearby villages, most non-pedestrian traffic moved on one-speed bicycles, with only an exterior ring road partly paved. Only $6 \%$ of the entire division's population (80 000) was considered "urbanized". Today, Makueni County (including Kibwezi as 1 of 15 divisions) remains more rural than Kenya overall ( $88 \%$ vs. $68 \%$ ) and with a higher poverty rate (64\% vs. $46 \%$ ) (KNBS, 2020). Only $10 \%$ of the population has secure title to land, which is experiencing rapid environmental degradation in a semi-arid region with a $75 \%$ rainfall failure rate. Deep poverty induces people to migrate to Nairobi, Mombasa, and neighboring countries in search of waged work, with social fragmentation including higher-than-national HIV/AIDS rates. Population clusters in Mbuinzau Hill Sublocation northwest of Kibwezi and the Masongaleni Resettlement Area to the southeast (both now crossed by SGR) connect Kenya's dependence on safari tourism with a complicated history since the 1930s of multiple evictions of tens of thousands of people from the Chyulu Hills to the southwest, now part of the vast Tsavo National Park.

Kibwezi's outward appearance has changed over time (personal observation). Twenty years ago, Kibwezi town had only single-story buildings; today, four- and five-story buildings dominate the center and large, multistory private homes are scattered throughout the outskirts. Electricity and running water are commonplace. There are four banks, and cellphones typically connected to Kenya's M-Pesa mobile money network are ubiquitous. Roads into the interior have increased truck traffic through town, not just past it, and a

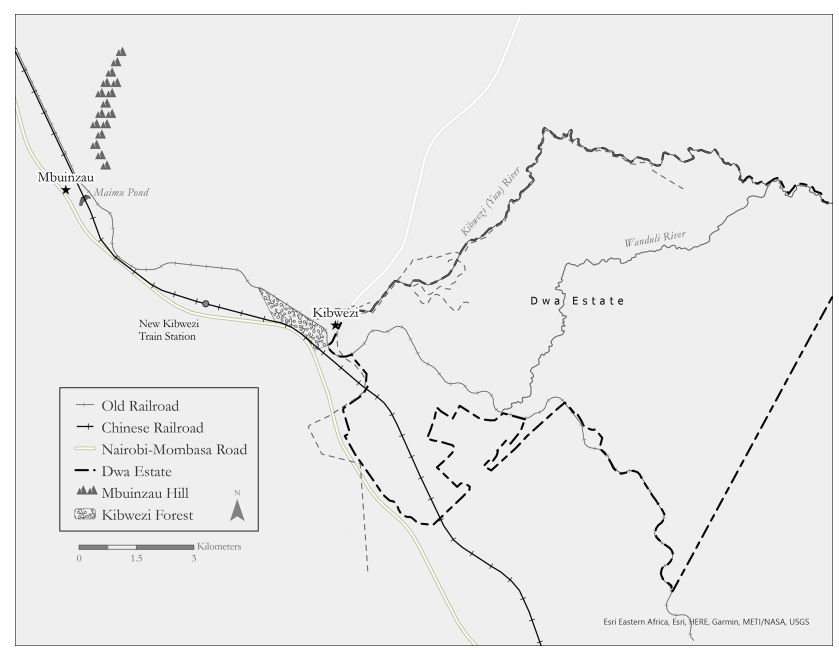

Figure 1. General study area, showing the locations of Kibwezi and Mbuinzau towns, Mbuinzau Hill, the Dwa Estate, and other relevant features.

highway bus stop has improved long-distance transit. In 2008 the import duty on Chinese-made motorcycles was eliminated, prompting a 24-fold increase in numbers nationally within just 5 years. In Kibwezi, even children within walking distance of school pay for a boda boda ride and private academies compete with the overcrowded public school. Nearly every street is paved, and a supermarket diminishes the traditional open-air market. But while Kibwezi's urban population has more than doubled, the division's urban share has remained constant, with persistent settlement of landhungry poor exacerbating economic stratification.

Likewise, more than a century of land disputes with a 22 475-acre (9095 ha), British-owned sisal plantation called the Dwa Estate on Kibwezi town's eastern edge have become more aggravated, both because the estate hopes to repurpose the fiber crop as biofuel and now by SGR's environmentally disastrous arrival. Kibwezi now has two railway stations, but only the old one scheduled for closure is actually in town, opposite the government's gigantic grain stores, the police station, and main market, while the sparkling new station is a 40 min walk to the west (see Fig. 1). What little train traffic used to stop at Kibwezi now rushes past as part of statistics celebrating supposedly improved service.

\section{Angles of arrival under the harmonious railway - SGR's dreamscape on the ground}

Since a dreamscape's viability depends on sociotechnical imaginaries to implement hoped-for visions of the future (Jasanoff and Kim, 2015), Roselle urges attention is paid to "what means and methods of persuasion and influence are likely to work under what conditions" when such "strategic narratives" simultaneously "explain the world and set constraints on the imaginable and actionable, and shape per- 
ceived interests" (Roselle et al., 2014:71 and 74). Foreclosing the possibility of alternative narratives involves deployment of evaluative metaphors drawing on shared cultural knowledge (Charteris-Black, 2003). Thus, the first Belt and Road Forum in 2017 opened with a rhetoric of "inclusive globalization" (Liu and Dunford, 2016) during a "lovely season... when every living thing is full of energy" (Xi, 2017), emphasizing "a bridge for peace and East-West cooperation" and "not a solo but a symphony." Tacit assumptions were made that "East" and "West", "bridge", "peace", and even "symphony" were understood by everybody in the same, unproblematic way. Similarly, the phrase "Connecting nations, prospering people" appears on the side of SGR's express engines, but before you can question which nations are being connected, how and why they are being connected, or what exactly is meant by "prospering" (or even the difference between "nations" and "people"), the train has rushed past.

The same is the case with the design of SGR's nine passenger stations. Nairobi Terminus supposedly resembles two sleek, modern engines facing one another representing Kenya and China, an additional structure laid atop them meant to be a bridge. When the line heading southeast reaches Emali, the meeting point of Maasai and Akamba cultural geographies is depicted by a station resembling two closed fists as a sign of unity. Confusion about why open hands or hands holding one another had not seemed more appropriate illuminates the fact that Chinese contractors, not local peoples, controlled design processes.

SGR public relations rhetoric claims Kibwezi's new station design with large triangular extensions resembles "African architecture" and "trees that shield passengers from the sun" (Mwende, 2019), though traditional Kamba houses are round and Ukambani is dominated not by broadleaf trees but by thorny acacia scrub vegetation and massive baobabs towering over the landscape with typically narrow canopies and small leaves. Further on, the sloping roof of Mtito Andei Station supposedly represents Mount Kilimanjaro and the Chyulu Hills even though the name Mtito Andei meaning "place of the vultures" refers to when the corpses of workers who died building the Lunatic Line were gathered there before being returned home to British India.

Where Kamba cultural geography yields to Taita territory, Miasenyi Station in the Taru Desert has prominent white and brown stripes, supposedly inspired by the patterns of zebras. Though it is unlikely the subtext intentionally references China's underdeveloped Kenyan partner, only immature animals have brown stripes. Coastal Mariakani Station's loggia looks more realistically like regional coconut trees, but landgrabbing for tourism and real estate development associated with SGR's construction has increased deforestation. SGR's arrival in Kibwezi has similarly reactivated strong feelings about sacred mathembo forests, many first destroyed by the Dwa Estate, whose investors own another sisal plantation between Mombasa and Kilifi being repurposed for luxury homes and golf courses for expatriates and Nairobi's elite.
SGR's visual rhetoric masks these troubled political ecologies, Mombasa Terminus' blue-tinted concentric circles resemble ripples in the ocean, and a central tower represents the splash from a dropped pebble inaugurating renewed contact between Africa and Asia.

This celebratory dreamscape often fails to translate well. Large blue and white banners I have seen outside SGR supply and equipment yards, excavation zones, cement factories, electrical stations, and work camps broadcasting messages in Chinese and English are rarely grammatically correct - including "In equal cooperation, work together for good money under the harmonious railway" (emphasis added). These issues only seem to vanish when banners appear exclusively in Chinese characters outside worker encampments, further underscoring difficulties strategic narratives face working in an idealized space of shared experience. Despite BRI's rhetoric about "inclusive globalization" (Liu and Dunford, 2016), SGR resulted from a purely bilateral deal; no competitive tender was offered to companies other than the Chinese contractor selected to carry out East Africa's largest infrastructure project of the last half century. Likewise, the state-owned China Road and Bridge Corporation operated with only 1 year of liability, and while China claims 25000 Kenyans are employed, Kenya counts fewer than 15000 . Also, while SGR's maiden journey was made in 2017, expectations of completely turning over staff to Kenyan control will not be satisfied until 2027. Most of the equipment on board the new trains and even much railway depot signage is labeled in Chinese, and only Chinese engineers drive the train between Nairobi and Mombasa; Kenyans are merely involved in shunting operations.

It is helpful here to recall the tension existing between what Bakhtin (1981, originally published 1934) called the "epic", striving for a hegemonic discourse assimilated by its audience, and the "novel" endlessly disturbed by so-called "hybrid utterances" with information always referencing indefinite chains of sources. Narratives may be selectively assimilated and/or contested among many different constituencies simultaneously, and because much of what counts as knowledge is non-verbal, what we normally consider to be narrative is unrepresentative of the whole range of possible expression (Bloch, 1998). Bakhtin refers to this as heteroglossia, with Kristeva emphasizing "the insertion of history (society) into a text and of this text into history" (Kristeva, 1980:68). China tries to elide such contending imaginations of future development via broadcast of a single message reinforcing BRI's dreamscape. In 2011, a subsidiary of the Chinese pay-TV operator StarTimes was awarded one of only two licenses for digital TV broadcasting in Kenya (the other given to the state-run Kenya Broadcasting Corporation). Competition from a consortium of private Kenyan companies broadcasting almost $90 \%$ of the country's analog signal was not allowed until a 2014 Supreme Court decision mandating competition. StarTimes' sociotechnical imaginaries predictably whitewash news about China in Africa, re- 
porting nothing to Kenyan subscribers about SGR's many problems. Now StarTimes is the most widespread digital provider in Kenya, but its Faustian tradeoff provides remote populations with access to the globe but only in a top-down, consumerist model of information exposure, heavily influencing subjectivities (Clausen, 2004; Lefkowitz, 2017).

\section{SGR in Kibwezi District - the revenge of landscapes?}

But material circumstances can get their revenge for efforts to foreclose alternative geographic imaginaries. In 2015, Kenyans working on SGR in Kibwezi reported language problems with Chinese supervisors with inadequate command of English (personal communication). Kenyan foremen who took over decision-making were reprimanded when things subsequently went wrong. Worse, Kibwezi sits in an ancient lava field composed of small kivuthini rocks of irregular shape. Passing Kibwezi, SGR is elevated about $6 \mathrm{~m}$ above grade, but kivuthini was used for embankment fill instead of standardized clay and sand aggregates, risking embankment collapse by being more vulnerable to infiltration. Indeed, rare flooding caused a devastating landslide near Kibwezi market in 1998, damaging a $3 \mathrm{~km}$ stretch of the highway so badly that cargo could not move inland. Maimu Pond fed by watercourses descending Mbuinzau Hill overtopped the old railway and cut hill villages off from direct access to Mbuinzau town below them (see Fig. 1). Such events have increased in frequency and strength (Abram et al., 2008), with the Green Africa Foundation warning SGR's intensive quarrying disrupts natural drainage. Between Mbuinzau Hill and Kibwezi, the Chinese have leased several plots for sand and particulate excavation, significantly worsening erosion problems. Along the whole length of SGR between the coast and Nairobi, gigantic volumes of windblown material from open quarries have smothered nearby shamba farm fields already separated from their households by the railway embankment. The irregular distribution of tunnels means local people must often walk longer distances than they did previously to get to everyday destinations. Fencing anchored to concrete posts sometimes inhibits use of even this limited circulation system, and some remote rural areas have been securitized with guards posted after fencing was subject to vandalism and theft.

SGR's most visible impact locally has been substantial damage to Kibwezi Forest (see Fig. 2). Housing a Kenya Forestry Research Institute (KEFRI) station, it has been a semi-legal source of household fuelwood and habitat for resident wildlife and includes mathembo shrines. SGR has significantly fragmented habitat, and local people believe it has also disrupted the dry area's all-important hydrology. The Chinese did not hire the large number of workers required to cut SGR's path through the forest with chainsaws but used bulldozers to push down trees. Some were giant baobabs eas-

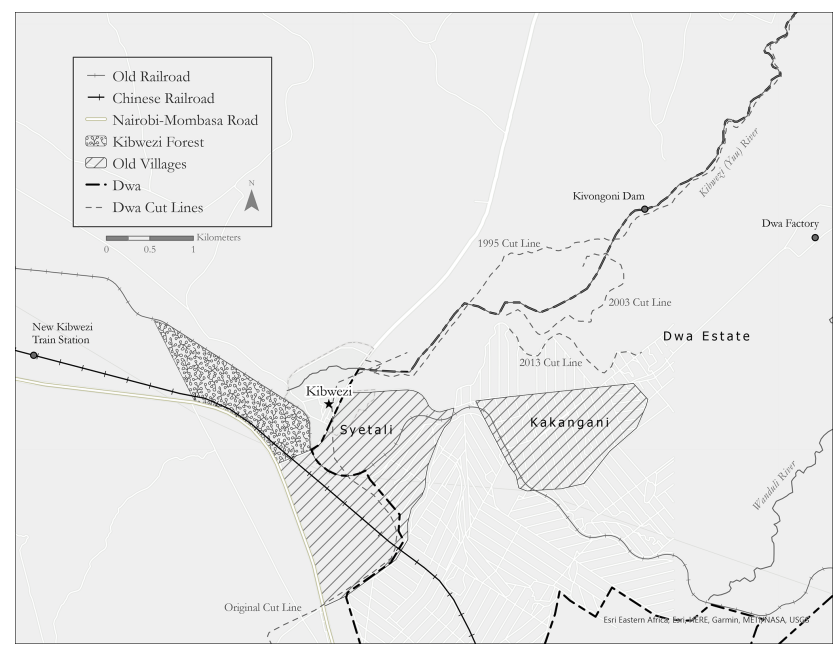

Figure 2. Detailed view of the relationship of SGR with Kibwezi Forest, the Dwa cut lines, and the evicted villages of Syetali and Kakangani.

ily hundreds of years old, and other species were also of great cultural value to local people and the scientific community alike. Most of this downed timber was simply dragged to the side of the construction route and left there, and local people were denied government permission to take advantage of this unhappily supplied source of fuelwood without paying considerable fees.

Bad feelings rose quickly, and at least once a group of Chinese required an armed police escort to go shopping in Kibwezi given residents' fury at the damage SGR was doing to the area. Chinese workers staying overnight in Kibwezi insisted on booking all the rooms of a hotel to avoid contact with local populations, and when they stayed outside town, they remained in gated encampments. As much figurative as topographic, claims to place are as much about "sentimental sovereignty" as they are about formal adjudication (Greyser, 2017).

Moreover, because "vernacular landscapes" of lived experience are only ever seen "out of the corner of one's eye" (Jackson, 1984), the subjects of alternative narratives of change are not necessarily populations articulating them but material aspects of local landscapes through which people rework their collective past (Walley, 2004; Shetler, 2007). What matters less than people accurately remembering a place's history is how the conditions of "accuracy" are defined and redefined as the contexts in which memory is deployed change. For example, the name "Kibwezi" means "to stand akimbo", a reference to Kamba farmers disturbed by the noise of the Lunatic Line walking away from shambas to stand by the railway hands on hips frowning in disapproval. This history has reemerged almost as a kind of "right" to stand askance in regard to SGR's disruptions locally, as though to say grievance was already "authorized" by the advent of the first railway. The town's name thereby developed 
by usage of a meaning not directly deducible by the strict meaning of the word kibwezi, instead becoming sentimentally idiomatic.

Such a particularly local expression of place identity allows something seemingly small-scale to generate more diffuse denotations across time and space. Consider the long history of grievances about the Dwa Estate. Starting in 1909, Dwa exploited the colonial British authority's alienation of indigenous people to evict populations of at least 13 so-called "lost" villages. Even though only a third of the immense estate is actually planted with sisal today, several entrances are gated and staffed by armed guards (askari). Dwa's sprawling western and northern borders follow the Kibwezi River - also called the Yuu (see Fig. 1) - along which frequently violent history since the 1930s has unfolded involving seven newer villages made up of descendants of those evicted from the estate. Askaris have assaulted boys herding animals, sexually assaulted women, torched shambas, and installed concrete boundary "beacons" at night. Buffer strips have been bulldozed or cut at least three times (in 1995, 2003, and 2013), with high concentrations of herbicide sprayed to clear vegetation including crops.

The landscape still bears evidence of these so-called "Dwa lines" (see Fig. 2). When the return of multiparty democracy in 2003 prompted talk of constitutional reform defining ownership of land in terms of "productive" use, Dwa bulldozed the remaining area of the lost village of Syetali to plant fresh sisal. On 200 acres ( 81 ha) south of the estate's present western gate between the old railroad and the highway, Syetali's landscape was modified again when SGR received government permission to bulldoze Dwa's sisal there in 2015. Local people outraged that the estate was compensated for this clearance tried in 2016 to blockade the Syetali construction site. Armed with traditional bows and poisoned arrows, villagers insisted that if changing land use was an option, the government should have recognized still-remembered histories of indigenous settlement. The modern railway has been used to resurrect memories of the Lunatic Line's impacts on Kibwezi to argue Dwa's 947-year lease of land is invalid because it was negotiated with the British and not with the Kenyan government, which should not consider itself obligated to compensate the estate for lost sisal before adjudicating village claims that would vacate the plantation's expectation of being taken seriously by the Chinese.

Nonhuman landscape elements gain active agency at this point, with affect encompassing more than emotion when sensation becomes as fundamental as signification (Massumi, 2002). Townspeople's complaints are not only about quantified volumes of water now missing in the Kibwezi River or about particular fig trees cut down to make room for another multistory building erected by "strangers" but also about changing relationships with forests and fish that have much to do with defining the community's identity. Those squatting along the Dwa lines can rarely point to specific landscape markers of former villages bulldozed long ago, but that hardly makes their sense of those places less substantial, especially now that SGR intersects the landscapes of expropriation and violence on the estate's southern periphery.

At stake is not just a precursive feeling about place but the intensity of that emotional connection, understanding "place" as a field of intensities constantly changing relations with one another. Representational forces such as maps, texts, and photographs try to render the world as intelligible but reduce lived experience to a second-order phenomenon, while affective geographies reassert intimacy with landscape stretching across time and distance. The photographer Tayiana Chao documented dozens of stations along the Lunatic Line in a project called Save The Railway (Chao, 2017). Making sure her pictures were not left to speak for themselves, an exhibition includes public review; field interviews with local people near each station; accounts of Chao's own experiences traveling across the country before SGR demolished her targets; and social media commentary posted by a community throughout Kenya and across the globe with personal memories of taking the old railway to school, to work, and on holidays or a honeymoon. Polyvalent production of meaning intensifies feeling to achieve reflective engagement with both the place of memory and the place of futures not circumscribed by SGR's dreamscape. Such comments as "Just see how all the railway stations have the same look and feel" connect a generalized emotional reaction to Chao's photographs to a more particular intensity about diminished pasts - "Its sad to see a railway tower that once had workers watching through the windows for trains coming or going" - and to reflections about the future - "As a country, we should be careful that SGR doesn't end up the same way".

\section{The Chinese and the chief's tree}

Affect has both the seeming insubstantiality and unavoidable presence of an "inventory of shimmers", but Seigworth and Gregg insist it is not "always already sutured into a progressive or liberatory politics" (Seigworth and Gregg, 2010:10). Stubbornly neutral, this is not simple indifference to existing conditions, with affect "elud[ing] easy polarities and contradictions". Not an event in time, a location in space, or a body positioned at a particular juncture of the two, affect is an interval composed of intensities of interaction "that pass body to body (human, nonhuman, part-body, and otherwise)" (Seigworth and Gregg, 2010:1). As Swyngedouw (2004:18) puts it, "Every body and every thing ... is a mediator, part social, part natural, lacking discrete boundaries and internalizing the multiple contradictory relations that redefine and rework them".

So how does appreciation for the dynamic presence of affective geographies help us make sense of sociotechnical imaginaries and reactions to them? Jasanoff (2007) suggests a need for methods or "technologies of humility" to accommodate the partiality of knowledge about the future 
in order to "reflect on... sources of ambiguity, indeterminacy and complexity". From a comparison of British and Brazilian examples, Macnaghten and Guivant (2011) likewise call for critical consideration of significant cultural variability in public engagement with sociotechnical imaginaries. An emphasis on partiality and particularity implies taking ethnographic approaches to investigation. As already noted in reference to the language used in the Belt and Road forums in 2017 and 2019, as well as in Chao's multiform archive about the Lunatic Line, discourse analysis of spoken and written words in formal and informal contexts is important, as is that of representational images. As already shown, this involves paying attention to speeches, policy documents, blogs, promotional slogans at construction sites and those emblazoned on locomotives, and even the architecture of SGR's stations. Inasmuch as success of a dreamscape's spatial reorderings depends on how well it is received at a visceral level in advance of description or declaration, SGR's streamlined development model is also confronted by affective, hybrid geographies in Kibwezi that are significantly nonrepresentational. The task remaining here is to engage with some of those geographies.

The Kamba universe is saturated with energy never entirely containable by a single body, human or nonhuman, with core concepts of $u w e$ and uoi reflecting intensities and trajectories toward maintenance of order or its disruption, respectively, including relations between the visible world of the living and that of аimu spirits of the dead still actively occupying the same landscape. A person able to "positively" manipulate this energy is called ти'unde ти'uwe but necessarily understands how to work uoi and therefore is susceptible to becoming mu'unde mu'uoi. Such "power" often involves deployment of a kit of supplemental means of exerting it called kyondo (typically kept in a small bag). Some individuals are even said to be shapechangers (mganga).

While mu'unde mu'uoi work in ways we might read as "bad", there is more to their role in local landscapes than that. As a young man, Mr. Mathu from Mbuinzau Hill went to work in western Kenya's tea plantations after he had finished at the Kibwezi mission school. He came back with a well-practiced English accent and a Brooke Bond Kenya bush hat and other mannerisms intended to affect his sense of self-importance compared to those who had stayed behind. But then he built his house in the colonial rather than traditional style without getting permission from the aimu and his elders. A much-feared mu'unde mu'uoi and mganga who owned a bar on the highway had already used his power to kill a man coveting his youngest wife by binding his victim's fate to the survival of a tree soon uprooted by the government to widen the road. When the mu'unde mu'uoi encountered aimu upset with Mathu's new cinder-block house, the sorcerer changed himself into a whirlwind and blew down the house, with Mathu inside.

Whether such tales are true is beside the point. "Modern" housing is now common throughout Kibwezi; the current fashion is to build sprawling "Nigeria houses" in the style of mansions seen on West African soap operas (often broadcast by China's StarTimes). At issue is not change per se but a "right" sort of relationship to place in the process, that is, appropriately affective change. Mr. Mathu soon rebuilt his house in nontraditional materials again but only after appeasing supposedly aggravated aimu. Even Dwa's managers understand the necessity of appearing sensitive to Kamba cultural ecology; they have been assisting July bull sacrifices at Kivongoni Dam (see Fig. 2) since violent clashes with squatters in recent years.

The most intense affective geographies are those associated with mathembo forests and springs associated with aimu presences. Rather importantly, an ithembo is much more than just a location, with the stem verb - thembo - meaning "offerings". Therefore, an ithembo is a place defined by action; more than a location in the present, it is a zone of historical and also potential happenings instead, always in association with particular flora and fauna. The procedure of initially recognizing an ithembo's existence involves communication with "spirits of the wilderness", with anxiety rising when wilderness is no longer perceived to exist in the area, which is particularly relevant considering the affective geographies of mathembo plowed under a century ago to plant Dwa's sisal or more recently bulldozed in Kibwezi Forest for SGR. That many mathembo are hierarchically interrelated, especially when several are part of the same hydrologic system, also has much to do with how and why people react to SGR's environmental impacts.

Mathembo sites still exert a gravitational force for social action. Christianization often targets the felling of individual trees associated with ithembo ritual, for example. But even nominally Christian Kamba engage the services of a mu'unde mu'uwe at desiccated mathembo spring sites in hopes of convincing аimu to provide relief when a dry season lingers. Mathembo also frequently serve as important rhetorical devices for commenting on modern water development projects. On Mbuinzau Hill, the National Council of Churches of Kenya constructed a wellhead around Ithembo ya Kwakyongo in 1985 . It was dry by 2011 , according to local people because the church had disturbed the site's energy. Again, what is at stake is the intensity of interactions between bodies. As an unmistakable example of affective geography, locals often say water "doesn't like" concrete commonly used in local construction.

A women's group called a ngolano traditionally maintained rules of access to mathembo and meted out social punishments on those who disrespected local sacred geographies. In 1988, the ngolano famously mobilized to chastise a man for shooting a 17-foot $(5 \mathrm{~m})$ python in an ithembo on the small Kangesu River adjacent to the old railway just outside Kibwezi. While nobody enjoyed having the snake around, a creature that big was taken as a sign of a healthy ecosystem, and in the Kamba way of thinking its killing disrupted the balance between uoi and uwe. The man eventually moved af- 
ter modern drilling equipment no longer provided him with irrigation water. Taken by some as an appropriate punishment for his action, the persistence of water shortages in the area since then also symbolizes the connection of the community to the individual - nature's response to his misbehavior having become a pervasive, collective punishment. The gendered character of the ngolano's authority to intervene in environmental issues also reflects Kibwezi Division's significant number of female-headed households given male labor migration. In 2015, the ngolano interrupted Chinese work crews when SGR cut through Maimu Pond at the foot of Mbuinzau Hill (see Fig. 1).

Whatmore calls for "an upheaval in the binary terms in which the question of Nature has been posed and a recognition of the intimate, sensible, and hectic bonds through which people, organisms, machines, and elements make and hold their shape in relation to each other in the business of everyday living" (Whatmore, 1991:26, emphasis added). SGR is about bonding - a train track seems an unproblematic route between two points, origin and destination, with comings and goings functionally equivalent. But a deep Kamba tradition about never taking the same path lest uoi find its way across the landscape of human interactions means circulatory motion is heavily symbolic; sacrifices at the important Ithembo ya Kwa Muthita require walking a spotless black bull completely around the foot of Mbuinzau Hill.

Colors vitalize microspatializations in Kibwezi. Red, black, and white cloths traditionally hang in trees marking mathembo entrances. White is peaceful and cleansing, and black is associated with watchfulness and appealing to aimu for goodwill. Houses constructed of modern materials and outfitted with such typical consumer goods as televisions and refrigerators nonetheless are painted with a broad black band just above the foundation. Red is associated with judgment. In 2015, small acts of sabotage involved relocating the red flags of SGR construction markers or planting decoys embodied with carefully prepared curses against work crews and their equipment. The dreamscape's technological bond with local geography repeatedly is made "hectic" as the railway tracks' linearity is complicated by different sorts of localization and movement.

At the heart of local affective geographies, the trees of Kibwezi Forest are not merely trees (Rocheleau and Ross, 1995). They simultaneously mark vestiges of displaced people's ancestral villages, Dwa Estate's expectation of compensation for bulldozed resources, the temporal edge of sisal soon to transform from a fiber crop into biofuel, and in the KEFRI arboretum parts of a revitalized scientific discourse about species richness now lost to the railway. Just as familiar landscapes have been rendered unfamiliar in disfigurement, trees still standing and trees pushed down are no longer recognizable as what they once were presumed to be. None of these versions of Kibwezi's trees is superior, although different interests vie for their version to have the greatest affective impact on anybody paying attention.
Otherwise contending forces can combine and recombine. Reflecting historical changes in Ukambani's wider cultural ecology, aimu are not necessarily exclusively Kamba ancestral spirits, some Maasai, Gikuyus, or even Europeans are associated with specific geographies and/or family lineages. Talk of hectic bonds lines up with Luongo's talk of the "fraught" experiences of Akamba trying to balance living between uoi and uwe (Luongo, 2011:7). Lacking a shamba of his own to farm, Mr. Koka earns his keep working as Dwa's askari assigned to Kivongoni Dam. Near his post is the "bleeding" bamboo, a dense stand several meters high said to be reincarnated spirits of the villagers of Kilui who drowned for ignoring the plight of neighbors evicted by plantation colonialists. A notorious Dwa general manager ordered the bamboo cut down despite warnings this would disturb Kilui's anguished aimu. Predictably, when workers ran away in fear of the bamboo bleeding at first contact with their machetes, the manager took up the task only to drop dead. Again, veracity does not matter here, and the way the guilty of Kilui were narratively deployed to punish Dwa's guilt opened up possibilities of similar narratives being constructed around SGR's arrival.

But perhaps the most revealing example involves the reinvention of Kilundo Meli. At the turn of the 20th century, the Presbyterian Church of East Africa (PCEA) laid claim to $64 \mathrm{~km}^{2}$ of land stretching from Kibwezi town all the way to the crest of Mbuinzau Hill after negotiating a deal with Kilundo. But Kilundo was also a powerful mu'unde $m u$ 'uoi, and when he and his neighbors were soon pushed off their lands by plantation interests, Kilundo supposedly used his power to kill three missionaries without touching them and then disguised their burial sites. When the PCEA Kibwezi school is visited today by missionaries from abroad, they never travel in Kibwezi alone and always stay inside a walled compound otherwise. Like any mu'unde mu'uoi, Kilundo's reputed power was as much technical as embodied, and locals believe that he often buried his kyondo beneath an ithembo tree so that the spiritual energy of his accoutrements could be recharged.

Some in Kibwezi have now reinvented Kilundo as a chief around whose memory they hope to rally resistance to government collaboration with the Chinese negatively impacting their lives. But precolonial Akamba did not have chiefs; communities traditionally organized along clan lines by gender and age grades - even today, ngolano groups have no leaders except to the degree that an organizational structure has been borrowed from Western cultures. Indeed, it was the British who imposed the Chiefs' Act in 1937, creating salaried civil service positions for administrators of locations (with an assistant chief for each sublocation and a village elder in each village, with only the latter elected by local people). The act was maintained with only minor revisions after independence and subject to only a partial repeal in 1997. There are those locally who believe mathembo were better protected when chiefs were able to wield nearly unchecked power. During 
droughts and famines in the 1980s, Chief Munandu Mwololo protected critical resources through use of corporal punishment and intimidation.

Precisely because of how hated the act was and for how long it was hated, it is fascinating that Kilundo is now often referred to as a chief given such authority was promulgated decades after his death in 1901 by the government now being blamed for allowing SGR to destroy local landscapes. His reinvention is also meant to suggest that the PCEA swindled the chief, misleading him about how the deal he made permitted expropriation of his land and that of his neighbors. Yet this assumes today's definitions of property ownership and market exchange can be applied to the situation that existed more than a century ago when, in fact, Kilundo was in no position to have negotiated with the PCEA as it claims he did.

Finally, there is Kilundo's kyondo and the ithembo tree under which he sometimes would bury it. Again, in Kamba tradition an ithembo is not personal property of any sort (though there are several mathembo in the area named for individuals closely associated with their histories), and the mu'unde mu'uoi's harmful, disruptive actions do not easily align with the socially reinforcing purposes of mathembo rituals. For that matter, one local story insists that Kilundo's kyondo was destroyed shortly after his death. But today, the chief's kyondo lives on; many of those outraged by the wanton destruction of Kibwezi Forest caused by the Chinese insist that Kilundo's tree could not be removed and that the mи'unde mu'uoi's power still invested there is actively working to punish supporters of SGR for what has happened locally. It does not matter that which tree in particular is supposed to be Kilundo's depends on who you ask, especially given that the mathembo known to be in the forest are associated with the Kibwezi River's water now diverted for SGR's construction. The point instead is that mathembo are increasingly becoming sites for affective commitments to environmental and sociocultural conservation in the face of development pressures.

\section{Conclusion - strenuous poetry}

Xin and Matheson (2018:4262) ask, "What happens to the power to produce certain images when their mediated reception is hyperconscious...? Are such narratives... diminished when the hearer is listening for the strategic moves?" Certainly, by the time of the Second BRI Forum in 2019, China had "adopted a more nuanced tone, talking about the environment, sustainability, better oversight and anti-corruption measures rather than focusing on the sheer scale of BRI projects" (Balakrishnan, 2019). While BRI was still situated within a "lovely season" (Xi, 2017), a more subdued rhetoric recognized that the commitment required both is more strenuous than expected and needs to be more reflective, with talk about friends getting together "to climb up mountains and write poems" (Pham, 2019). Earlier talk of easy cooperation gave way to a need "to be guided by the principle of extensive consultation [and] joint contribution". Likewise, some of the international community's complaints about violations of intellectual property protection were acknowledged, as was the need for China to "promote sustainable development". But Pham reported the second forum to be a "chaotic" affair "lacking a clear schedule and sufficient content" to adequately promote its new emphasis on transparency and accountability, and television coverage of a roundtable discussion only included comments by China's leadership and not those of any attending BRI partner countries.

Clifford noted that "the currency of culture and identity as performative acts can be traced to their articulation of homelands, safe spaces where the traffic across borders can be controlled ... Cultural action ... takes place in the contact zones, along ... policed and transgressive ... frontiers. Stasis and purity are asserted - creatively and violently - against historical forces of movement and contamination" (Clifford, 1997:7). At the outset, I asked, how successful are dreamscapes (Jasanoff and Kim, 2015)? The answer is that success depends on the degree to which they are adopted and in which forms, with reactions in Kibwezi to SGR's futurism revealing the "purity" of "safe spaces" is never limited to specific sites but to intensities of interactions between variable imaginaries. The other questions initially posed are now also answered. Dreamscapes may be opposed not only by equally grandiose alternative narratives but also by more localized imaginaries, and while dreamscapes are future-oriented, alternatives referencing the past can compete well.

Affective geographies are energized by precisely the condition of changing local conditions paradoxically exploited to reaffirm a sense of place (Kottak, 1980), so "postequilibrial" approaches to understanding development can helpfully evaluate SGR's impacts. "New ecology" (Scoones, 1999) emphasizing adaptive disturbance and dynamic social-environmental relations reconceptualizes the supposed boundedness of one geography relative to others both human and nonhuman (Gillson et al., 2003). As with indigeneity (Ellen, 2007), we should wonder when and why equilibrium is emphasized in particular contexts. Instead of wondering what happens when material reality has its revenge and the whole SGR scheme collapses, it is more important to wonder how deeply its dreamscape can take root in Kenya and why (Ferguson, 1990; Escobar, 1995). A "forest fundamentalism" (Buttel, 1992:19) about Kibwezi's copses, springs, and other mathembo landscapes would wrongly presume tiny enclaves on Mbuinzau Hill or along the Dwa lines are sturdy and indeed expandable. Protests about the devastation wreaked by the Chinese in Kibwezi Forest, in the sisal plantation, and at the foot of Mbuinzau cannot be taken automatically as promotion of sustainably alternative visions of development locally, but they do reveal much about how in- 
terests might be organized to promote at least some sort of alternative to SGR's dreamscape.

Likewise, there is a powerful need to recognize that facts on the ground do not support a clear distinction of sacred and profane landscapes (Sheridan, 2008). Mathembo are at least as politically charged as the secular areas which dominate Kibwezi. Both colonial rule and post-independence transformations of Kenya politicized sacred spaces many times in many ways. Not a unilinear process, with nonlocal forces defining landscapes in ways to which local people often can respond only after the fact, the history of Kibwezi's sacred landscapes is one of persistence and even preemption of challenges rather than reaction to them alone, and meanings of particular socio-environmental relations in and between particular sites are sometimes vigorously defended, contested, and adapted to all at once.

From a postequilibrial perspective, it should be noted that many supposedly "traditional" and local mathembo have come into being because of, not in resistance to, trends generally considered modern and national or even global. An ithembo may be claimed as ancient and intensely indigenous even as it is often a material expression of how local people have adopted, modified, and resisted Westernization. This is part of the story about which of the lost villages of Syetali and Kakangani historically was home to Kilundo Meli (see Fig. 2). Those who claim the so-called chief for Syetali do so in part because it is the only village ever to manage any kind of collective access to Kenya's courts, however dim the prospect now seems of a final judgment in favor of ancestral claims to the land. Paradoxically, there are also Syetali descendants willing to lay claim to the residual affective power of Kilundo's name because of, not despite, the fact that early Christian converts of the community supposedly burned his kyondo after his death. Meanwhile, those claiming Kilundo belonged to Kakangani say Syetali suffered evictions after, not before, his kyondo was destroyed and note that Kakangani was the village where the Dwa managers built their railway station and first boundary gate. At the symbolic center of this capitalist resource exploitation there is supposed to be the Ithembo ya Kakangani, revealed to local people only after the arrival of the plantations.

So, needing to examine practices of coordination, decision-making, and investment in globalizing dreamscapes, we should also recognize opportunities for vigorously negotiating alternatives to the geographies they promote. Kibwezi's mathembo are not refuges for emasculated traditional customs and institutions but are sites and resources that are as much affective as material and discursive for their revitalization in the contexts of changed times. Socionature (Swyngedouw, 1996) is an unavoidable hybrid, despite dreamscape efforts to pretend otherwise. Since local people hold that mathembo are not established, demarcated, or defined by human action but exist pre-discursively and energize attention to be directed to appropriate locations, there is no final instance in which society determines nature. In the same way, dreamscapes are unable to have the last word where local affective geographies are concerned, or even the first, really.

Of course, it is worth investigating whether and how cultural ecologies other than those explored here may also be shaping responses and alternatives to BRI's dreamscapes, regarding sites not only outside Kibwezi but also within it. While Akamba populations dominate the region, colonial and postcolonial histories have involved other identities there too. Before independence, Dwa Estate hired significant numbers of Luos from Kenya's Lake Victoria region. A much earlier history of Swahili contact established Kibwezi town's original version and continues to have a presence in one neighborhood there. A nearby Sikh community is home to descendants of South Asian laborers who built the Lunatic Line; Gikuyus related to the country's political and economic elite have speculated in land development in the area, and a handful of Europeans have established long-term personal connections to Kibwezi as well. For that matter, histories of repeated population displacement and resettlement are also tangled up with stories of other large infrastructure projects, including many like SGR brought in by foreign actors. Careful examination of differences in local responses to different categories of such projects (for example, comparing and contrasting SGR-like development efforts with more explicitly humanitarian interventions) is similarly clearly warranted.

In 2013 China defended its willingness to avoid imposing conditions on African regimes known for corruption, human rights abuses, and environmental neglect by suggesting "Only the wearer knows whether the shoes fit or not" (Xinhuanet, 2013). But how far is Africa willing to walk the same path with China, and for how long, and will the two feel the same way about it for as long as the journey lasts?

Data availability. No data sets were used in this article.

Competing interests. The author declares that there is no conflict of interest.

Acknowledgements. Thanks to Eddie Mwanzia, Monika Lawrence, and Sarah Anderson (for help with mapping).

Review statement. This paper was edited by Simon Runkel and reviewed by two anonymous referees. 


\section{References}

Abram, N. J., Gagan, M. K., Cole, J. E., Hantoro, W. S., and Mudelsee, M.: Recent intensification of tropical climate variability in the Indian Ocean, Nat. Geosci., 1, 849-853, https://doi.org/10.1038/ngeo357, 2008.

Anderson, B. and Harrison, P. (Eds.): Taking-place: Nonrepresentational theories and Geography, Ashgate Publishing, Farnham, UK, 2010.

Bakhtin, M. M.: The dialogic imagination: Four essays, edited by: Holquist, M., University of Texas Press, Austin, Texas, USA, 1981.

Balakrishnan, P.: Behind China's subdued BRI rhetoric, The Hindu BusinessLine, available at: https://www.thehindubusinessline. com/opinion/columns/behind-chinas-subdued-bri-rhetoric/ article26995266.ece (last access: 11 May 2020), 2019.

Beckert, J.: Imagined futures: Fictional expectations and capital dynamics, Harvard University Press, London, UK, 2016.

Behrends, A., Park, S.-J., and Rottenburg, R. (Eds.): Travelling models: Introducing an analytical concept to globalisation studies, in: Travelling models in African conflict management, Brill, Leiden, the Netherlands, 1-40, https://doi.org/10.1163/9789004274099_002, 2014.

Bhabha, H. K.: The location of culture, Routledge, New York, USA, 1994.

Bloch, M.: How we think they think: Anthropological approaches to cognition, memory, and literacy, Westview Press, Oxford, UK, 1998.

Buttel, F. H.: Environmentalization: Origins, processes, and implications for rural social change, Rural Sociol., 57, 1-27, https://doi.org/10.1111/j.1549-0831.1992.tb00454.x, 1992.

Chao, T.: Save the railway: A mission to preserve Kenya's antique railway stations, available at: http://www.savetherailway.com/ (last access: 11 May 2020), 2017.

Charteris-Black, J.: Speaking with forked tongue: A comparative study of metaphor and metonymy in English and Malay phraseology, Metaphor. Symbol., 18, 289-310, https://doi.org/10.1207/s15327868ms1804_5, 2003.

Clausen, L.: Localizing the global: "Domestication" processes in international news production, Media Cult. Soc., 26, 25-44, https://doi.org/10.1177/0163443704038203, 2004.

Clifford, J.: Routes: Travel and translation in the late Twentieth Century, Harvard University Press, Cambridge, Massachusetts, USA, 1997.

Edgerton, D.: The shock of the old: Technology and global history since 1900, Oxford University Press, Oxford, UK, 2006.

Ellen, R. F. (Ed.): Modern crises and traditional strategies: Local ecological knowledge in island Southeast Asia, Berghahn Books, New York, USA, 2007.

Escobar, A.: Encountering development: The making and unmaking of the Third World, Princeton University Press, Princeton, New Jersey, USA, 1995.

Ferguson, J.: The anti-politics machine: "Development", depoliticization, and bureaucratic power in Lesotho, Cambridge University Press, Cambridge, UK, 1990.

Flyvbjerg, B.: Machiavellian megaprojects, Antipode, 37, 18-22, https://doi.org/10.1111/j.0066-4812.2005.00471.x, 2005.
Gillson, L., Sheridan, M., and Brockington, D.: Representing environments in flux: Case studies from East Africa, Area, 34, 371389, 2003.

Greyser, N.: On sympathetic grounds: Race, gender, and affective geographies in nineteenth-century North America, Oxford University Press, New York, USA, 2017.

Harvey, D.: Justice, nature, and the geography of difference, Blackwell, Oxford, UK, 1996.

Jackson, J. B.: Discovering the vernacular landscape, Yale University Press, New Haven, Connecticut, USA, 1984.

Jasanoff, S.: Technologies of humility, Nature, 450, 33, https://doi.org/10.1038/450033a, 2007.

Jasanoff, S. and Kim, S. H.: Containing the atom: Sociotechnical imaginaries and nuclear power in the United States and South Korea, Minerva, 47, 119-146, 2009.

Jasanoff, S. and Kim, S. (Eds.): Dreamscapes of modernity: Sociotechnical imaginaries and the fabrication of power, University of Chicago University Press, Chicago, Illinois, USA, 2015.

Jones, O. and Cloke, P.: Non-human agencies: Trees in place and time, in: Material agency: Towards a non-anthropocentric approach, edited by: Knappett, C. and Malafouris, L., Springer, Heidelberg, Berlin, Germany, 79-96, 2008.

KNBS: Kenya National Bureau of Statistics: Makueni County profile, available at: https://www.knbs.or.ke/?wpdmpro= makueni-county, last access: 11 May 2020.

Kottak, C. P.: The past in the present: History, ecology, and cultural variation in highland Madagascar, University of Michigan Press, Ann Arbor, Michigan, USA, 1980.

Kristeva, J.: Desire in language: A semiotic approach to literature in art, Columbia University Press, New York, USA, 1980.

Lawrence, C.: Heralds of global transparency: Remote sensing, nuclear fuel-cycle facilities, and the modularity of imagination, Soc. Stud. Sci., 50, 508-541, 2020.

Lefkowitz, M.: Chinese media, Kenyan lives: An ethnographic inquiry into CCTV Africa's head offices, China Africa Research Initiative, School of Advanced International Studies, Working Paper 9, Johns Hopkins University, Washington, DC, USA, 24 pp., 2017.

Liu, W. and Dunford, M.: Inclusive globalization: Unpacking China's Belt and Road Initiative, Area Dev. Policy, 1, 323-340, https://doi.org/10.1080/23792949.2016.1232598, 2016.

Luongo, K.: Witchcraft and colonial rule in Kenya, 1900-1955, Cambridge University Press, Cambridge, UK, 2011.

Macnaghten, P. and Guivant, J. S.: Converging citizens? Nanotechnology and the political imaginary of public engagement in Brazil and the United Kingdom, Publ. Underst. Sci., 20, 207220, 2011.

Massumi, B.: Parables for the virtual: Movement, affect, sensation, Duke University Press, Durham, North Carolina, USA, 2002.

McCormack, D.: Diagramming practice and performance, Environ. Plan. D, 23, 119-147, https://doi.org/10.1068/d51j, 2005.

Mwende, J.: Kenya Standard Gauge Railway, available at: https://www.constructionkenya.com/2720/ standard-gauge-railway-kenya/ (last access: 6 April 2021), 2019.

Ndlovu-Gatsheni, S. J.: Global coloniality and the challenges of creating African futures, Strat. Rev. South. Africa, 36, 181-202, 2014. 
Pham, T. N.: Deep Dive: The Second Belt and Road Forum, Center for International Maritime Security, available at: http://cimsec. org/deep-dive-the-second-belt-and-road-forum/40460 (last access: 11 May 2020), 2019.

Pile, S.: Emotion and affect in recent human geography, T. I. Brit. Geogr., 35, 5-20, https://doi.org/10.1111/j.14755661.2009.00368.x, 2009.

Rocheleau, D. and Ross, L.: Trees as tools, trees as text: Struggles over resources in Zambrana-Chaucey, Dominican Republic, Antipode, 27, 407-428, https://doi.org/10.1111/j.14678330.1995.tb00287.x, 1995.

Roselle, L., Miskimmon, A., and O'Loughlin, B.: Strategic narrative: A new means to understand soft power, Media War Conflict, 7, 70-84, https://doi.org/10.1177/1750635213516696, 2014.

Schiølin, K.: Revolutionary dreams: Future essentialism and the sociotechnical imaginary of the fourth industrial revolution in Denmark, Soc. Stud. Sci., 50, 542-566, 2010.

Scoones, Y.: New Ecology and the social sciences: What prospects for a fruitful engagement?, Annu. Rev. Anthropol., 28, 479-507, https://doi.org/10.1146/annurev.anthro.28.1.479, 1999.

Seigworth, G. J. and Gregg, M.: An inventory of shimmers, in: The Affect Theory Reader, edited by: Gregg, M. and Seigworth, G. J., Duke University Press, Durham, London, UK, 1-28, 2010.

Sheridan, M.: The dynamics of African sacred groves: Ecological, social, and symbolic processes, in: African sacred groves: Ecological dynamics and social change, edited by: Sheridan, M. and Nyamweru, C., James Currey, Oxford, UK, 9-41, 2008.

Shetler, J. B.: Imagining Serengeti: A history of landscape memory in Tanzania from earliest times to the present, Ohio University Press, Athens, Ohio, USA, 2007.

Smallman, M.: "Nothing to do with the science": How an elite sociotechnical imaginary cements policy resistance to public perspectives on science and technology through the machinery of government, Soc. Stud. Sci., 50, 589-608, 2019.

Swyngedouw, E.: The city as hybrid: On nature, society, and cyborg urbanization, Capital. Nat. Social., 7, 65-80, https://doi.org/10.1080/10455759609358679, 1996.
Swyngedouw, E.: Modernity and hybridity: Nature, Regeneracionismo, and the production of the Spanish waterscape, 18901930, in: Reading economic geography, edited by: Barnes, T. J., Peck, J., Sheppard, E., and Tickell, A., Blackwell, Malden, Massachusetts, USA, 189-204, 2004.

Thrift, N.: Non-representational theory: Space, politics, affect, Routledge, London, UK, 2007.

Turnbull D.: Masons, Tricksters and Cartographers: Comparative Studies in the Sociology of Scientific and Indigenous Knowledge, Harwood Academic Publishers, Amsterdam, the Netherlands, 2000.

Walley, C. J.: Rough waters: Nature and development in an east African marine park, Princeton University Press, Princeton, New Jersey, USA, 2004.

Watson-Verran, H. and Turnbull, D.: Science and other indigenous knowledge systems, in: Handbook of Science and Technology Studies, edited by: Jasanoff, S., Markle, G., Petersen, P., and Pinch, T., Sage Publishers, London, UK, 115-139, 1995.

Whatmore, S.: Hybrid geographies: Rethinking the "human" in human geography, in: Human geography today, edited by: Massey, D., Allen, J., and Sarre, P., Polity Press, Cambridge, UK, 22-39, 1991.

Whatmore, S.: Hybrid geographies: Natures, cultures, spaces, Sage Publishers, London, UK, 2002.

Xi, J. P.: Full text of President Xi's speech at opening of the first Belt and Road Forum, Xinhuanet, available at: http:// news.xinhuanet.com/english/2017-05/14/c_136282982.htm (last access: 11 May 2020), 2017.

Xin, J. and Matheson, D.: One Belt, competing metaphors: The struggle over strategic narrative in English-language news media, Int. J. Commun.-US, 12, 4248-4268, 2018.

Xinhuanet: Commentary: Xi's maiden foreign tour historic, fruitful, Xinhuanet, available at: http://news.xinhuanet.com/ english/indepth/2013-03/31/c_132274914.htm (last access: 11 May 2020), 31 March 2013. 